\title{
Židovská komunita v roku pandémie (prípadová štúdia)
}

\author{
The Jewish community in the year of the pandemic \\ (a case study)
}

DOI: 10.31577/EtnoRozpra.2021.28.2.01

\section{Peter Salner}

\section{Abstract}

This paper analyses how the Jewish community in Bratislava dealt with the first and second waves of the COVID-19 pandemic that took place between 1 March 2020 and 30 May 2021. Because the public health measures in force at the time rendered traditional ethnological research methods inapplicable, the author's main source of information was the online communication of the leadership and administration of the Bratislava Jewish Religious Community (JRC) with its members. On 9 March 2020, the government implemented the first battery of public health measures. Already on that same day, the JRC released a newsletter encouraging its members to observe the authorities' guidance. It also cancelled all of its scheduled activities. The leadership would go on to distribute masks and hygiene supplies to the oldest members of the community, facilitate the vaccination of Holocaust survivors. Part of Slovak society compared restrictions on social contacts, a mask mandate, and a limitation on free movement to the suffering of the Jews in the Wartime Slovak State, highlighting this supposed parallel by wearing yellow stars.

The effective limits on social contacts brought communal life within the community to a standstill, which had a particular effect on the older generations. The pandemic also inevitably led to a ban on communal worship and necessitated adjustments in the observance of traditional Jewish holidays, particularly Pesach. In many families, the communal Seder supper was held online via Zoom or Skype. The community also had to improvise during Hannukah, with an Orthodox or liberal rabbi assisting in the lighting of candles in the homes of members who requested it. 


\section{Key words}

COVID-19, Jewish community, public health measures, the pandemic and the Holocaust, social contacts, holidays

\section{Klúčové slová}

COVID-19, židovská komunita, verejné hygienické opatrenia, pandémia a holokaust, spoločenské kontakty, sviatky

\section{Acknowledgment}

Štúdia vznikla v rámci grantu VEGA 2/0047/21 „Človek v nedemokratických režimoch. Roky 1938 - 1989 v pamäti slovenskej majority a židovskej komunity. Etnologický pohl'ad."

\section{Kontakt / Contact}

PhDr. Peter Salner, DrSc., Ústav etnológie a sociálnej antropológie SAV, Klemensova 19, 81108 Bratislava, Slovenská republika, e-mail: peter.salner@savba.sk

ORCID (iD) https://orcid.org/0000-0002-6844-0235

\section{Ako citovat' / How to cite}

Salner, P. (2021). Židovská komunita v roku pandémie (prípadová štúdia). Etnologické rozpravy, 28(2), 8-23. https://doi.org/10.31577/EtnoRozpra.2021.28.2.01

\section{Úvod}

Priebeh a opatrenia spojené s pandémiou COVIDU-19 vyvolali v časti slovenskej verejnosti paralely s osudom židov ${ }^{1} v$ období holokaustu. Považujem preto za zaujímavé všimnút si, ako sa s touto situáciou vyrovnala židovská komunita v Bratislave. Zároveň sa pokúsim naznačit’ niektoré širšie súvislosti.

Z časového hl'adiska sa venujem obdobiu, ktoré sa začína 1. marca 2020, teda niekol'ko dní pred prvým zaznamenaným prípadom koronavírusového ochorenia na Slovensku a končí sa 31. mája 2021, ked’ doznievala druhá vina. V rámci tzv. kovidového automatu prakticky na celom území štátu platil už len úzky okruh obmedzení.

Pandémia, jej následky a formy boja proti ochoreniu predstavujú komplexný fenomén, ktorý má nielen zdravotné, ale aj ekonomické, spoločenské, psychologické, politické, a $v$ neposlednom rade aj morálne aspekty. Rozsah a nejasné okolnosti vzniku nákazy vytvárajú zároveň podmienky pre šírenie konšpiračných teórií. Preto je dôležité, aby sa touto problematikou zaoberalo čo najširšie spektrum spoločenských vied vrátane etnológie.

1 Výsledky sčítaní ludu v období 1930 - 2011 ukazujú, že vo všetkých prípadoch sa k vierovyznaniu hlási násobne viac osôb než k národnosti, preto som uprednostnil formu žid. 
V priebehu výskumu som sa zameral hlavne na najväčšiu židovskú komunitu na Slovensku. Vychádzal som z predpokladu, že organizačné štruktúry Židovskej náboženskej obce v Bratislave (ŽNO BA) a Ústredného zväzu židovských náboženských obcí (ÚzŽ$\mathrm{NO})^{2}$ dokážu úspešne zvládnut' problémy, ktoré COVID-19 prináša.

V úsilí potlačit nákazu vláda schválila aj kroky, ktoré je za iných okolností možné interpretovat ako porušovanie demokratických práv občanov. Vznikla tak situácia, ktorá negatívne ovplyvnila každodenný život obyvatel'ov a skomplikovala aj možnosti výskumu. K prijatým opatreniam patrila okrem iného prísna izolácia spojená s obmedzením osobných kontaktov a prechodným zákazom vychádzania. Neskôr vláda vyhlásila a opakovane predlžovala núdzový stav. $V$ dôsledku toho som bol nútený obmedzit tradičné etnologické spôsoby zberu materiálu (rozhovor, priame pozorovanie). V rámci možností som využíval nepriame formy výskumu a telefonickú komunikáciu so známymi, v prvom rade sa však opieram o internetovú korešpondenciu vedenia a administratívy ŽNO so svojimi členmi. Poznatky etnografie ${ }^{3}$ rozširujem o informácie $z$ dennej tlače, ale tiež o poznatky, ktoré som získal počas dvoch desatročí pôsobenia v štruktúrach ŽNO Bratislava a o vlastné skúsenosti. Chtiac či nechtiac som totiž bol súčastou niektorých procesov, zúčastnil som sa na testovaniach v priestoroch obce, realizoval som improvizované sviatočné aktivity. $V$ priebehu tohto výskumu som bol v pozícii pozorovatela.

\section{Prehistória}

Na úvod niekol'ko údajov o najväčšej židovskej komunite na Slovensku. V roku 1940, krátko pred začiatkom deportácií (z Bratislavy prvý transport odišiel 26. marca 1942), sa k židovskému vierovyznaniu prihlásilo 15102 osôb, čo bolo približne 12\% obyvatelov mesta (Lárišová, 2000: 9). Po oslobodení bolo v meste približne 3000 židov, teda asi pätina pôvodného stavu, pričom čast tohto počtu tvorili novopristahovalci, ktorí sem prišli až po skončení druhej svetovej vojny (Eichler, b. d.: 71). Alija (vystahovalectvo do Palestíny/lzraela) na prelome štyridsiatych a pätdesiatych rokov, ${ }^{4}$ emigračná vlna po okupácii Československa armádami Varšavskej zmluvy v auguste $1968,{ }^{5}$ generačná obmena, ale aj pasivita mladších členov komunity v období tzv. normalizácie $(1970-1989)^{6}$ spôsobili, že v súčasnosti sa počet členov ŽNO Bratislava pohybuje okolo čísla 500. Počas pandémie sa negatívne prejavila skutočnost', že na rozdiel od minulosti žijú rozptýlení na území celého mesta, čo oslabuje možnosti sociálnej kontroly, vzájomnej komunikácie, ale aj zdravotnej či sociálnej pomoci v prípade potreby.

\footnotetext{
2 Úlohou ÚZŽNO je koordinácia aktívnych obcí a správa majetku zaniknutých ŽNO. Z tohto dôvodu komunikuje viac s vedením obcí a s inštitúciami (štátnymi aj židovskými), než s jednotlivými členmi ŽNO. V porovnaní s obcami sú aktivity zväzu preto menej viditel'né a zdanlivo menej dôležité.

3 Etnologickú analýzu internetovej komunikácie využívam opakovane už dlhší čas. K možnostiam tejto metódy pozri Kozinets, 2015.

4 Podl’a dostupných údajov sa v tomto období do Palestíny/lzraela vystahovalo 10498 Židov (Jablonková, 1998: 166).

5 Etnologické aspekty emigrácie bratislavských židov po auguste 1968 pozri napr. Bumová (2006a) a Salner (2006).

6 Podrobnejšie sa touto problematikou zaoberal napríklad Hlavinka (2005) a Bumová (2006b).
} 


\section{Začiatky pandémie}

Spočiatku verejnost’ chápala pandémiu skôr ako geograficky vzdialenú kuriozitu, než ako reálnu hrozbu. Tieto postoje sa začali menit', ked' 6. marca 2020 médiá priniesli informáciu o výskyte ochorenia na Slovensku. Prvé konkrétne opatrenia vláda zaviedla 9. marca 2020. Vedenie ŽNO BA ešte v ten istý deň internetovým obežníkom vyzvalo svojich členov, aby ich dodržiavali. Text d’alej upozorňoval, že od nasledujúceho dňa (10. marca 2020) ŽNO BA ruší všetky plánované aktivity vrátane pravidelných ranných modlitieb v Ohel David. ${ }^{7}$

Rýchla reakcia vedenia ŽNO ohrozila slávenie židovského sviatku Purim. Začínal sa práve 9. marca večer a na nasledujúci deň rabín Baruch Myers v spolupráci s obcou organizoval vo Vzdelávacom centre Chabad Slovensko oblúbenú Purimovú zábavu. Podla e-mailovej pozvánky súčast’ou programu okrem tradičného čítania Megily ${ }^{8}$ mali byt’ aj „,... masky, trojchodová perzská hostina, profesionálne tetovanie hennou a vel'ká tombola s možnost’ou výhry luxusného hotelového pobytu, elektroniky alebo letenky do Tel Avivu“.

Napriek spomenutej výzve ŽNO rabín Myers chcel podujatie uskutočnit. Predpoludním 10. marca 2020 e-mailom informoval členov ŽNO BA, že požiadal Regionálny úrad verejného zdravotníctva o informáciu,
...či je možné v tomto období organizovat’ podujatie pre menšiu uzavretú skupinu nám známych l’udí z Bratislavy v priestoroch, ktoré sú vydezinfikované. Pracovníčka uvedeného úradu uviedla, že za týchto okolnosti nie je nevyhnutné podujatie zrušit', avšak zdôraznila, že treba dodržiavat' isté opatrenia (napr. časté umývanie rúk, atd'.) podla odporúčania Ministerstva zdravotníctva. Teraz je nevyhnutné upevnit’ našu dôveru v B-ha a „posilnit” sa“ micvami, ${ }^{9}$ ktoré nám prikázal v náš prospech. Toto je vskutku jediná cesta zabezpečit’ si svoje zdravie, bezpečnost’ a kontinuitu nášho národa.

ŽNO BA sa od akcie dištancovala, napriek tomu sa však uskutočnila, hoci s menšou účast’ou, než organizátori očakávali.

Vedenie obce rozhodlo, že až do odvolania administratíva bude pracovat’ v obmedzenom režime a za prísneho dodržiavania hygienických opatrení zo strany zamestnancov, aj prípadných stránok. Rýchlu reakciu ŽNO pozitívne ovplyvnilo to, že na jej čele stojí lekár. Už v prvých dňoch pandémie zamestnanci sociálneho oddelenia roznášali respi-

7 Ohel David, jediný židovský domov dôchodcov na Slovensku, spravuje ÚzŽNO. Má celoslovenskú pôsobnost' a prioritne je určený pre l'udí, ktorí prežili holokaust. Funguje od roku 2010, v súčasnosti má kapacitu 45 lôžok. ÚZŽNO zabezpečil opakované testovanie a napokon aj očkovanie personálu a klientov. Vd’aka tomu, na rozdiel od mnohých Domovov seniorov na Slovensku, v Oheli do konca októbra 2021 nik na COVID-19 neochorel.

8 Megila Ester pripomína, ako král’ovná Ester zachránila v 5. storočí pred občianskym letopočtom židovský národ. Účast' na jej čítaní patrí medzi najväčšie micvy (Newman, Sivan, 1992: 140).

9 Micva (mn.č. micvot) - náboženský predpis či prikázanie, ktoré je veriaci žid povinný plnit’ (Newman, Sivan, 1992: 115). 
rátory a dezinfekčné prostriedky. Prednostne ich dostali príslušníci najstaršej generácie alebo chronicky chorí ludia. Z reakcie predsedu obce je zrejmé, že tento „protekcionizmus" sa stretol s kritikou časti členov, ktorí tieto pomôcky nedostali. Zvolený postup vysvetlil Tomáš Stern nasledovne:

To, že ochranné masky boli distribuované v minulých dňoch poberatel'om obedov, nie je zdôvodnené uprednostňovaním niektorých našich členov pred tými ostatnými! Dôvodom bol obmedzený počet dostupných masiek, ktoré som poskytol priamo z môjho zdravotníckeho zariadenia. Poberatel'om obedov bol doručený preto, lebo náš tím ZNO a predovšetkým sociálne oddelenie, na čele s Vandou U. pracuje na hranici svojich kapacít (o ohrození vlastného zdravia ani nehovorím). Distribúcia poberatel'om obedov bola preto logisticky najjednoduchšia. Skutočný stav je ale taký, že d’alšie ochranné predmety nevieme kvôli ich nedostupnosti na trhu obstarat' skôr, ako v lehote 7-9 dní. Pevne ale veríme, že už v priebehu tohto týždňa budeme môct' distribuovat' medzi našich členov - prioritne seniorov, aspoň menší počet základných masiek a dezinfekčných materiálov. ${ }^{10}$

V rámci protipandemických opatrení obec uzavrela jedáleň pre stravníkov, čo negatívne zasiahlo najmä sociálny život l'udí, ktorí prežili holokaust. Mnohí z nich žijú osamotene a z predošlých skúseností viem, že do jedálne chodili viac zo spoločenských dôvodov, než kvôli strave. ${ }^{11} Z a$ normálnych okolností im priestory ŽNO BA ponúkali možnost' komunikovat $v$ bezpečnom prostredí s rovesníkmi, ktorí mali podobné životné skúsenosti a problémy. Telefón, skype či zoom nedokázal v plnej miere nahradit osobné kontakty, navyše nie každý senior ovládal techniku v potrebnom rozsahu. „Hygienická izolácia“ tak ešte viac zvýraznila spoločenské handicapy vyplývajúce z veku a zhoršovania zdravotného stavu. Kóšerná kuchyňa však nad’alej varila a zamestnanci obce doručovali obedy všetkým záujemcom (teda nielen chorým a starým) domov.

\section{Testovanie a očkovanie}

Už niekol'ko dní po prvom objavenom prípade tlač zverejnila prognózu d’alšieho vývoja. Z údajov Národného centra zdravotníckych informácií (NCZI) vyplývalo, že na jeseň 2020, ked' mala pandémia vrcholit', bude na Slovensku približne pol milióna nakazených a desattisíce mŕtvych. ${ }^{12}$ Tieto čísla sa ukázali ako prehnané, ale možno práve vd’aka nadsadeným údajom obyvatelia disciplinovane dodržiavali vládne inštrukcie. Ich súčastou bola karanténa, ktorá odporúčala prácu z domova a zakazovala osobné stretnutia s členmi iných domácností, vrátane rodinných návštev. Utrpela tým najmä najstaršia generácia, ktorá prišla o kontakty so svojimi det’mi a vnúčatami. K opatreniam d’alej patrilo povinné

10 Hromadný email rozoslaný 17. marca 2020 (Súkromný archív autora).

11 Potvrdzuje to aj skutočnost', že viacerí si v súčasnej situácii neobjednávajú dovoz obedov z obce, hoci túto službu ponúka, ale varia si sami, prípadne využívajú niektorú z jedální v ich okolí.

12 Správa bola uverejnená 17. marca 2020. Prvú vInu COVIDU-19 Slovensko úspešne zvládlo. 29. mája 2020 oficiálne údaje uvádzali 1520 nakazených a 28 mítvych (Eliáš, 2020). Stav o rok neskôr však ukazuje, že „čierny“ scenár nebol nereálny. Po skončení druhej vlny evidovali 390436 pozitívne testovaných osôb

12 a 12366 úmrtí (Ministerstvo investícií, regionálneho rozvoja a informatizácie Slovenskej republiky, 2021). 
nosenie rúšok na verejnosti, odstup od iných l'udí, používanie dezinfekčných prostriedkov, ale aj vyhradené hodiny, počas ktorých mohli v obchodoch nakupovat' len seniori starší ako 60 rokov. Politici, ale aj mnohí odborníci vyzdvihovali úspešný výsledok prvej vlny. ${ }^{13}$ Tento optimizmus vyvolal v spoločnosti pocit určitej bezstarostnosti, čo na jeseň 2020 viedlo k podceneniu druhej viny.

Ked' sa súčastou boja proti pandémii stalo antigénové testovanie, obec dala na tento účel k dispozícii svoje priestory. V priebehu apríla 2020 mailom informovali členov, že koncom marca ŽNO BA zorganizovala

...preventívne testovanie COVID-19 pre zamestnancov a členov sociálneho tímu ŽNO, ktorí zabezpečujú každodenný rozvoz potravín, ako aj starostlivost' o seniorov našej komunity. Za ich obetavú činnost' im aj touto cestou patrí naša vel'ká vd’aka. Začiatkom apríla (7. 4.) ŽNO zabezpečila aj vel'mi dôležité testovania zamestnancov Ohel David.

V e-maili d’alej záujemcom ponúkli

možnost' odberu v známom prostredí dvora nášho Komunitného centra ŽNO. Testovaná osoba tak nemusí íst' do jedného z masových odberových stacionárov. Každému záujemcovi bude pridelený presný odberový čas. Testovanie prebehne za prísnych protiepidemiologických opatrení, tímom špecialistov.

Nevýhodou ponuky bola vysoká (v tom čase však bežná) cena 70 eur za osobu. ${ }^{14}$

Po vypuknutí druhej vlny pandémie na jeseň 2020 obec poskytla priestory v štyroch kolách povinného celoplošného antigénového testovania aj verejnosti. $Z$ reakcií, ktoré som zaznamenal priamo na mieste, ale aj z následných neformálnych telefonických rozhovorov je zrejmé, že účastníci boli spokojní s organizáciou a plynulým priebehom testovania.

Pandémia ohrozovala najmä najstaršiu generáciu, preto bolo dôležité očkovat' l'udí, ktorí prežili holokaust. V spolupráci s ministerstvom zdravotníctva (a za prítomnosti vtedajšieho ministra Mareka Krajčího) sa uskutočnilo

...symbolicky pri príležitosti Medzinárodného dňa obetí holokaustu (27. január).

(...) K dnešnému dňu tak bolo zaočkovaných všetkých 128 preživších holokaust

z Bratislavy prvou dávkou vakcíny proti ochoreniu COVID-19, resp. vd’aka nasadeniu

členov sociálneho oddelenia ŽNO sú zvyšní preživší zaradení do očkovacieho

procesu v najbližších dňoch (Stern, 27. 1. 2021).

Symbolický dátum (predvečer sviatku Purim) zvolili aj pre druhé očkovanie. Sviatočný charakter akcie „...podporil svojou prítomnostou aj hlavný rabín ŽNO - Baruch Myers,

\footnotetext{
13 Pravidelné zasadnutia permanentného krízového štábu sa sobotným (13. 6. 2020) uplynutím núdzového stavu končia, zostáva však v pohotovosti. Potvrdil to člen permanentného krízového štábu Robert Mistrík a Úrad vlády. V statuse na Facebooku nazval svoj príspevok „Hnusobu sme porazili“ (Redakcia, 2020).
}

14 Pri prvom testovaní v rámci druhej viny pandémie (1. novembra 2020) sa uvádzala suma 20 eur pre člena ŽNO, 25 eur pre nečlena, napokon však bolo antigénové testovanie bezplatné a všetky náklady hradil štát. 


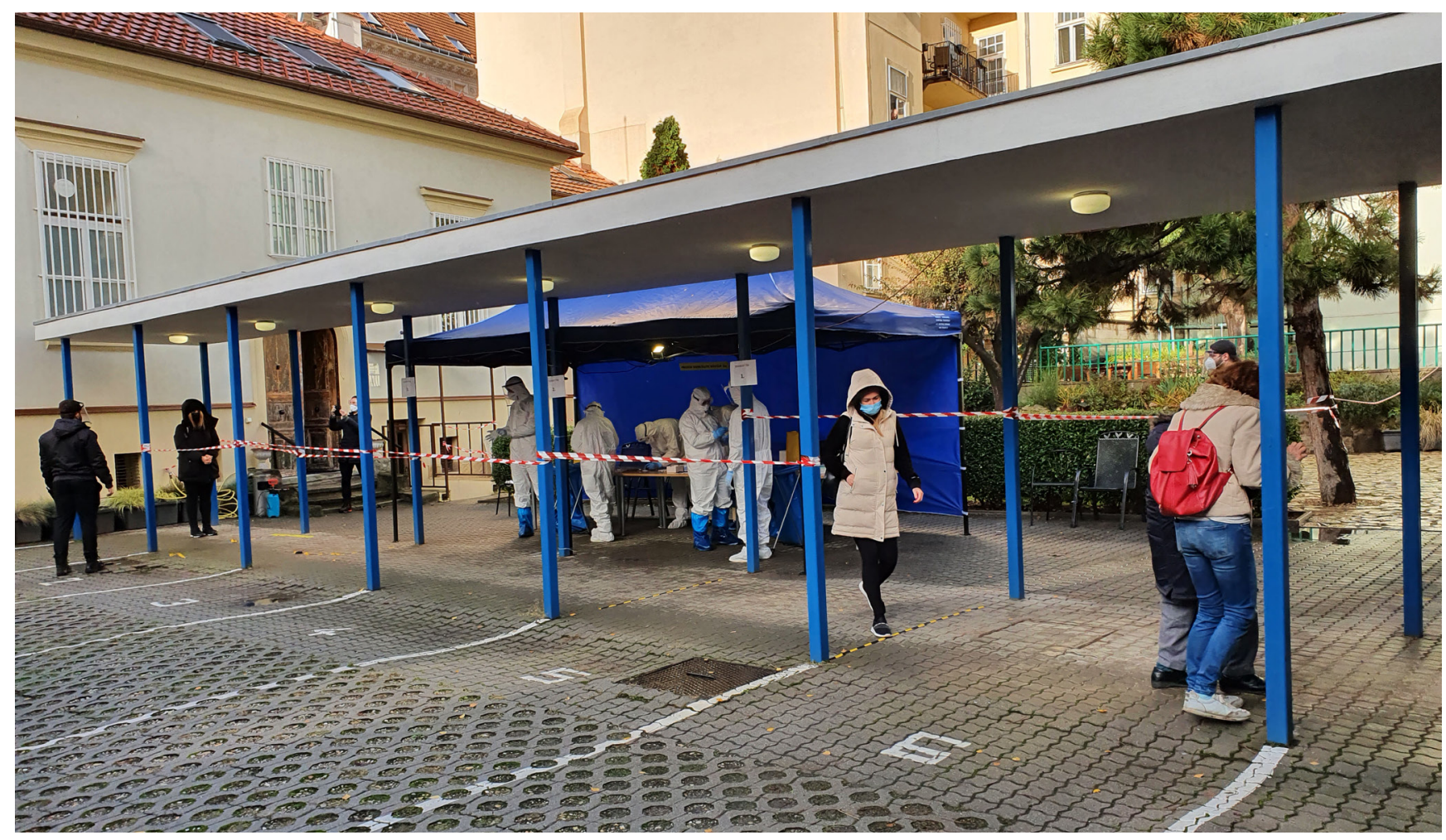

Obr. 1.

Testovanie na dvore ŽNO Bratislava. Zdroj: Peter Salner, 2020.

ktorý $v$ purimovom kostýme prispel k odlahčeniu celkovej atmosféry. Každý očkovaný navyše obdržal tradičný Mišloach manot.“15

Uvedené pozitíva neznamenajú, že komunite sa pandémia vyhla. Jednotlivé obce ohlásili prípady ochorenia i úmrtia svojich členov. Ochorel aj predseda ÚZŽNO Richard Duda:

Komunitnú Chanuku dnes večer budem pozerat’ z nemocničného lôžka. Priatelia, mám covid. Prísne som dodržiaval opatrenia, napriek tomu sa mi nepodarilo vyhnút nákaze. Priebeh mám komplikovaný, doslova o pät minút dvanást’ som sa dostal k profesorovi Jarčuškovi a primárovi Novotnému do košickej nemocnice. Konečne som bez horúčky a začínam dianie okolo seba vnímat'. Ten, kto to nezažil a nevidel na vlastné oči, si situáciu nedokáže predstavit. Zdravotníci sú hrdinovia. A nech to neznie ako klišé. Lekári a lekárky, zdravotnícky personál, sanitári a sanitárky robia nadl'udskú prácu. Denno-denne majú viac práce, tak, ako im ubúda pozitívne diagnostikovaných kolegov a pribúda pacientov v zlom stave. Som nesmierne vd’ačný a d’akujem všetkým, ktorí mi zachránili život a aj tým, ktorí ma kontaktovali, mysleli na mňa a modlili sa za moje uzdravenie. Najtažšie chvíle doterajšieho života som prežil počas sviatku, ktorý je založený na zázraku. Odteraz nielen Chanuku, ale i celý život vnímam úplne inak. Ďakujem za život, d’akujem za vašu podporu. ${ }^{16}$

15 Židovská náboženská obec Bratislava, 26. 2. 2021. Ide o tradičný pesachový zákusok.

1416 E-mail zo dňa 16. decembra 2020 uverejňujem so súhlasom R. Dudu (Súkromný archív autora.). 


\section{Pandémia a holokaust}

Povinná izolácia či nosenie rúšok vyvolali opakované protesty časti verejnosti. V Bratislave sa uskutočnili napríklad 20. augusta, 7. októbra či 12. decembra 2020, ale aj 1. mája 2021. K najväčšej demonštrácii došlo 17. novembra 2020 (Denník N, 17. 11. 2020). Napriek zákazu zhromažd'ovania prišlo 15-20 tisíc l'udí, ktorí sa presúvali medzi Prezidentským palácom, Úradom vlády SR a parlamentom. Na jej priebehu sa podiel'ali najmä niektoré opozičné politické strany (Smer, Kotleba - L'udová strana naše Slovensko, mimoparlamentné Slovenská národná strana alebo Komunistická strana Slovenska). Rečníci požadovali zrušenie „nedemokratických“ obmedzení, vedome porušovali predpisy núdzového stavu, mnohí účastníci nemali rúška, ignorovali požadované odstupy od ostatných. Najmä futbaloví ultras fanúšikovia hádzali delobuchy, kvôli čomu nastúpili „policajní tažkoodenci a aj policajti na koňoch“. Z tlače vyplýva, že na týchto akciách sa zúčastnili aj známe osobnosti vrátane niektorých poslancov Národnej rady SR či bývalého predsedu Najvyššieho súdu SR Štefana Harabina. ${ }^{17}$

V nariadených opatreniach l'udia často hl'adali paralely s obdobím holokaustu. Na Facebooku kládli vedla seba fotografie židov, ktorí čakali v roku 1942 na transport do koncentračných táborov a l'udí, ktorí „trpeli“, pretože na antigénové testovanie museli dlhšie čakat' v radoch.

Čast’ antivaxerov manifestovala svoje utrpenie nosením žltej šest'cípej hviezdy, niekedy doplnenej nápisom Neočkovaný. V relácii TV JOJ sa expremiér Peter Pellegrini

...prirovnal k prenasledovaným Židom, ktorí museli počas obdobia holokaustu nosit”
žltú Dávidovu hviezdu: „Vy ste zasa vložili, prečo nepočujeme od Pellegriniho, že
sa ide dat’ zaočkovat'. No lebo som zatial’ v skupine l'udí, ktorí sa dobrovol'ne zatial'
očkovat’ nedajú. A čo je na tom zlé, idete mi dat’ sem (ukazoval na sako - pozn. red.)
hviezdu, aby som sa bál chodit’ po ulici?" pýtal sa moderátorky (Kern, 2021).

Početné a rôznorodé spektrum odkazov na holokaust ilustruje, že táto tragédia dnes rezonuje nielen $v$ židovskej komunite, ale aj v majoritnom prostredí, nie však v rovnakej rovine. Niektoré príspevky zároveň nasvedčujú, že l’udia často nepoznajú a nechápu (alebo vedome skresl'ujú) reálne utrpenie židov počas holokaustu. Logicky nasledovali nesúhlasné reakcie na takéto názory. Publicista Michal Havran v tejto súvislosti spomenul „...tradičných gangstrov, ktorí l’ud’om vtedy (počas druhej vlny pandémie - poznámka autora) hovorili, že nemajú nosit’ rúška, ktoré považovali, aká tupá hanba, za židovskú hviezdu“ (Havran, 2021). V kritickom duchu sa už počas prvej vlny vyjadrila blogerka Soňa Jánošová:

Dnes, ked’ sedím „uväznená“ v pohodlí svojho bytu, ked’ sa snažím pred ostatnými členmi rodiny zavriet’ do izby, aby som mala aspoň trochu vlastného priestoru, nevdojak mi v predstavách ožívajú telá tlačiace sa vo vagónoch pre dobytok. Ked’ si

17 Harabin vyslovil názor „Rúško som nenosil, nenosím a pokial” mi Pánboh dá zdravie, ani nosit nebudem“ (Harabin, 2021; Uhlárik, 2021). Nasadit’ rúško si Harabin odmietol aj počas pojednávania s Eliotom Rostasom na Najvyššom súde SR (Osvaldová, 2021). 
idem po dvadsiaty raz za deň umyt’ ruky mydlom, myslím na jediné vedro, do ktorého mal celý vagón robit' potreby. Ked' so znepokojením sledujem míňajúce sa zásoby v aj tak blahobytnej komore a spisujem zoznam potravín, ktoré treba dokúpit', myslím na potravu na tri dni, ktorú si dievčatá mohli so sebou zobratł. Pre väčšinu z nich išlo o posledné jedlo v živote. Prebiehajúcu pandémiu rozhodne nechcem zl'ahčovat' na úkor diania v 40-tych rokoch. Ked' však v týchto dňoch smútim za svojím niekdajším pohodlím a t’ažkám si nad komplikáciami, ktorých úlohou je ochránit’ mňa a mojich blízkych, začujem pískanie odchádzajúceho vlaku. Pripomína mi, že moja t’ažká jar je len skúškou pohodlia a disciplíny. Pripomína mi tých, ktorým nikto nepovedal, aby zostali doma (Jánošová, 2020).

Reminiscencie na vojnový slovenský štát sa objavili aj u l'udí z komunity, ktorí toto obdobie zažili: „Na začiatku izolácie mi skúsenost' z vojny pomohla. Nebolo pre mňa ničím novým sediet’ v byte a nesmiet íst’ von. Ako dievča som sedem mesiacov sedela za zamknutými dverami v obave o život“ (Rybárová, Mosnáková, 2021). Odvolávky na holokaust sa objavili aj v súvislosti s očkovaním preživších, o ktorom sa zmieňujem na inom mieste:

Týmto aktom sa podarilo napomôct' skrátit dobu izolácie práve tým, ktorí vo svojom živote už jednu nútenú izoláciu zažili. Vd’aka dnešnému očkovaniu pevne veríme, že sa tak budú môct' v dohl'adnej dobe zapojit’ opät’ do normálneho života. ${ }^{18}$

K zdanlivej podobnosti oboch období prispel tiež zákaz vychádzania, obmedzenie ciest do prírody, možnost’ prejst' do iného okresu len v rámci presne určených výnimiek. Situáciu vyostrilo, ked' po príchode druhej viny pandémie vláda vyhlásila od 1. októbra 2020 núdzový stav na celom území Slovenska: „V čase núdzového stavu môže štát v zmysle zákona obmedzit’ základné práva a slobody, a to v nevyhnutnom rozsahu, na nevyhnutný čas. Najdlhšie môže núdzový stav v zmysle zákona trvat’ 90 dní.“19 V tejto súvislosti chcem pripomenút, že obmedzenia prijali a kontrolovali demokraticky zvolené orgány štátu. Ciel’om nebola likvidácia demokratického systému či politických protivníkov, ale záchrana životov a zdravia obyvatel'ov. Trestom za zistené porušenia bolo napomenutie či peňažná pokuta, nemali teda pre previnilca fatálne následky. Prípadné nedostatky boli prejavom neschopnosti či nedostatku skúseností, nevyplývali však zo zlého úmyslu. Aj preto ich l'udia napriek prejavom nespokojnosti a hlasným vystúpeniam parlamentnej opozície väčšinou rešpektovali. Zároveň sa však ukázalo, že hrozbu možno zneužit a pod zásterkou boja s nebezpečenstvom relatívne jednoducho presadit zákony, ktoré premenia demokratický režim na autoritársky či dokonca na totalitný systém. Považujem to za d’alší dôvod, prečo je pandémiu potrebné skúmat’ nielen ako zdravotnícky problém, ale v širších ekonomických, politických a psychologických súvislostiach.

Odpor voči očkovaniu sa často spájal s nedôverou a obviňovaním židovskej komunity. Nejde o nový predsudok. Rovnaké korene mal aj najväčší protižidovský pogrom na Slo-

18 Úryvok z e-mailovej informácie o očkovaní preživších v priestoroch ŽNO (Súkromný archív autora.).

19 Vláda napriek výhradám opozície núdzový stav opakovane predlžovala (Ministerstvo vnútra Slovenskej republiky, 2020). Núdzový stav vláda ukončila v noci z 15. na 16. mája 2021, trval teda viac než 7 mesiacov (Madra, 2021). Postupy vlády kritizovala aj čast' ústavných právnikov. Ciel’om príspevku nie je rozbor právnych aspektov zavedenia a predlžovania núdzového stavu, preto viac podrobností neuvádzam. 
vensku po druhej svetovej vojne. Prebehol 24. septembra 1945 v Topol'čanoch. Vyvolala ho fáma, že židovský lekár vraj v miestnej škole očkovacou látkou vraždil krestanské deti. Rozvášnený dav vyvliekol doktora Bergera na námestie, kde ho surovo zbili. Neskôr $\checkmark$ domoch a na uliciach mesta fyzicky napádali židovských obyvatelov, ktorí sa nestačili ukryt'. Výsledkom bolo 47 zranených, z toho 15 tažko (podrobnejšie pozri Kamenec, 1988).

\section{Spoločenské kontakty v čase pandémie}

V „mierových“ podmienkach sa príslušníci bratislavskej ŽNO BA združovali hlavne v kluboch, ktoré sa formovali na základe podobného veku a záujmov. Pred vypuknutím pandémie aktívne pôsobil Klub seniorov, ktorí prežili holokaust. ${ }^{20}$ Napriek vysokému veku sa jeho členovia každý týždeň schádzali v priestoroch obce. K programu okrem „šmúzovania“" (nezáväzná spoločenská komunikácia) patrilo vystúpenie pozvaného hosta z radov umelcov, politikov či odborníkov a následná diskusia. Členstvo v The Hidden Child (Ukrývané diet’a) spája l'udí, ktorí prežili toto obdobie v detskom veku. ${ }^{21}$ Potomkovia preživších, narodení krátko po oslobodení (označovaní v odbornej literatúre ako „deti holokaustu“, ${ }^{22}$ prípadne „druhá generácia“) sa schádzajú v Klube Jachad, zatial' čo študentov združuje Slovenská únia židovskej mládeže.

Ako som už spomenul, súčastou protipandemických nariadení bola prísna izolácia. Toto opatrenie, ktoré negatívne zasiahlo činnost’ klubov, ponúkalo tri alternatívy riešenia: rezignáciu; porušovanie platných zákazov a napokon nahrádzanie osobných kontaktov technickými formami komunikácie (telefonáty, e-maily, skype, zoom atd'.). ŽNO BA sa zamerala na poslednú z uvedených možností. 18. 3. 2020 členom obce e-mailom ponúkli

\section{....aby sa pridali na oficiálnu Facebook stránku ŽNO. Prosíme, aby ste sledovali a venovali pozornost aktuálnym informáciám zo strany ŽNO BA, ktoré budeme priebežne na tejto stránke uverejňovat'. Vítané sú aj vaše postrehy a príspevky!}

K prvým výstupom novej komunikačnej platformy patrili jednoduché motivačné videá. Pripravovali ich (väčšinou formou nahrávky na mobil) oslovení predstavitelia komunity. Členovia obce dostali následne link, pomocou ktorého si mohli dané video pozriet'. Ako prvý takto vystúpil hlavný rabín Baruch Myers, nasledovali čestný predseda ÚzŽNO Pavel Traubner, predseda ŽNO Tomáš Stern, liberálny rabín Miša Kapustin, ale aj umelci, odborníci alebo sympatizanti. Spoločným prvkom týchto posolstiev bolo varovanie pred hrozbou pandémie, výzva dodržiavat' opatrenia, úsilie posilnit’ spolupatričnost' alebo divákov povzbudit’ pomocou židovského humoru.

20 Vznikom a fungovaním tohto klubu sa podrobne zaoberá zatial' nepublikovaná štúdia Moniky Vrzgulovej.

21 Zážitky členov THC spracovala Vrzgulová (2007).

22 Podrobnejšie k tejto problematike Epstein (1988), v českom preklade Epsteinová (1994). 


\section{Židovské sviatky $\vee$ dobe pandémie}

V tejto podkapitole vynechávam podrobnejšie opisy jednotlivých židovských sviatkov, pretože $v$ minulosti som im venoval samostatné príspevky. ${ }^{23}$ Tradičný priebeh sviatočných príležitostí znemožnil zákaz zhromažd’ovania. Situácia sa nezlepšila, ani ked’ NCZI povolila účast šiestich osôb na obradoch, pretože ani tento počet účastníkov nestačil na vytvorenie minjanu, ktorý je podmienkou riadneho priebehu bohoslužieb a iných obradov. $^{24}$

V inej súvislosti som spomenul napätie počas sviatku Purim na začiatku prvej vIny pandémie. Zaujímavé riešenia ponúkol d’alší jarný sviatok Pesach, ktorý má silný rodinný a komunitný rozmer. Karanténa znemožnila uskutočnit bohoslužby a následne spoločné sederové večere. Pretože bola zatvorená kancelária ŽNO BA, ešte pred začiatkom sviatku obec zorganizovala „lietajúci seder" a distribuovala pesachové produkty (macesy, kóšerné víno atd'.) priamo do domácností (podrobnejšie pozri Salner, 2020a: 162-163). V mnohých rodinách osobné stretnutia aspoň čiastočne nahradili zoom či skype.

Pri príležitosti sviatku LagBaOmer tradičné spoločenské stretnutie na dvore obce nahradil Koncert spolupatričnosti. Prenos internetovej česko-slovenskej židovskej televízie Tachles TV si pozrelo niekol'ko stoviek záujemcov. Vyvrcholením židovského výročného kalendára sú sviatky Roš HaŠana (Nový rok) a hlavne Jom Kipur (Deň zmierenia). Obe príležitosti pripadli na obdobie relatívneho uvol'nenia medzi prvou a druhou vinou pandémie. Za normálnych okolností prichádza na bohoslužby viac než 200 l'udí. V zmysle platných pravidiel v roku 2020 organizátori obmedzili v synagóge počet prítomných na 90 mužov a 50 žien. Do interiéru mohli vstúpit iba tí, čo sa vopred prihlásili. Každého z nich usporiadatelia usadili na vopred určené sedadlo. Navyše pripravili niekol'ko provizórnych miest na dvore synagógy.

Aj pri d’alšom sviatku obec improvizovala. V rámci „lietajúcej Chanuky“ ortodoxný rabín Baruch Myers alebo liberálny rabín Miša Kapustin asistovali pri zapal'ovaní sviečok v bytoch členov, ktorí o túto pomoc požiadali. ÚZŽNO prostredníctvom zoomu sprístupnil chanukový program pre deti na celom Slovensku.

\section{Záver}

Pandémia COVIDU-19 postavila židovskú komunitu (tak ako celú slovenskú spoločnost) pred zložité výzvy. Sonda do fungovania ŽNO BA v čase od 1. marca 2020 do 31. mája 2021 ukázala, že v tomto období obec primárne riešila 3 okruhy problémov. Prioritou bol boj proti nákaze (distribúcia zdravotných a hygienických prostriedkov, organizácia testovania, očkovanie preživších holokaust, pomoc pri prekonávaní následkov nútenej izolácie), d’alej náboženský život v podmienkach izolácie a napokon sociálne aktivity. Doterajšie dve viny pandémie komunita úspešne zvládla. Budúcnost’ ukáže, aké následky

23 Jarný cyklus židovských sviatkov počas pandémie som opísal v príspevkoch Salner, 2020a; Salner, $2020 b$.

24 Komunita rešpektovala zrušenie väčšiny náboženských podujatí, najmä pri pohreboch však vznikla náboženská a l'udská dilema, či porušit tradície judaizmu alebo protipandemické nariadenia. 


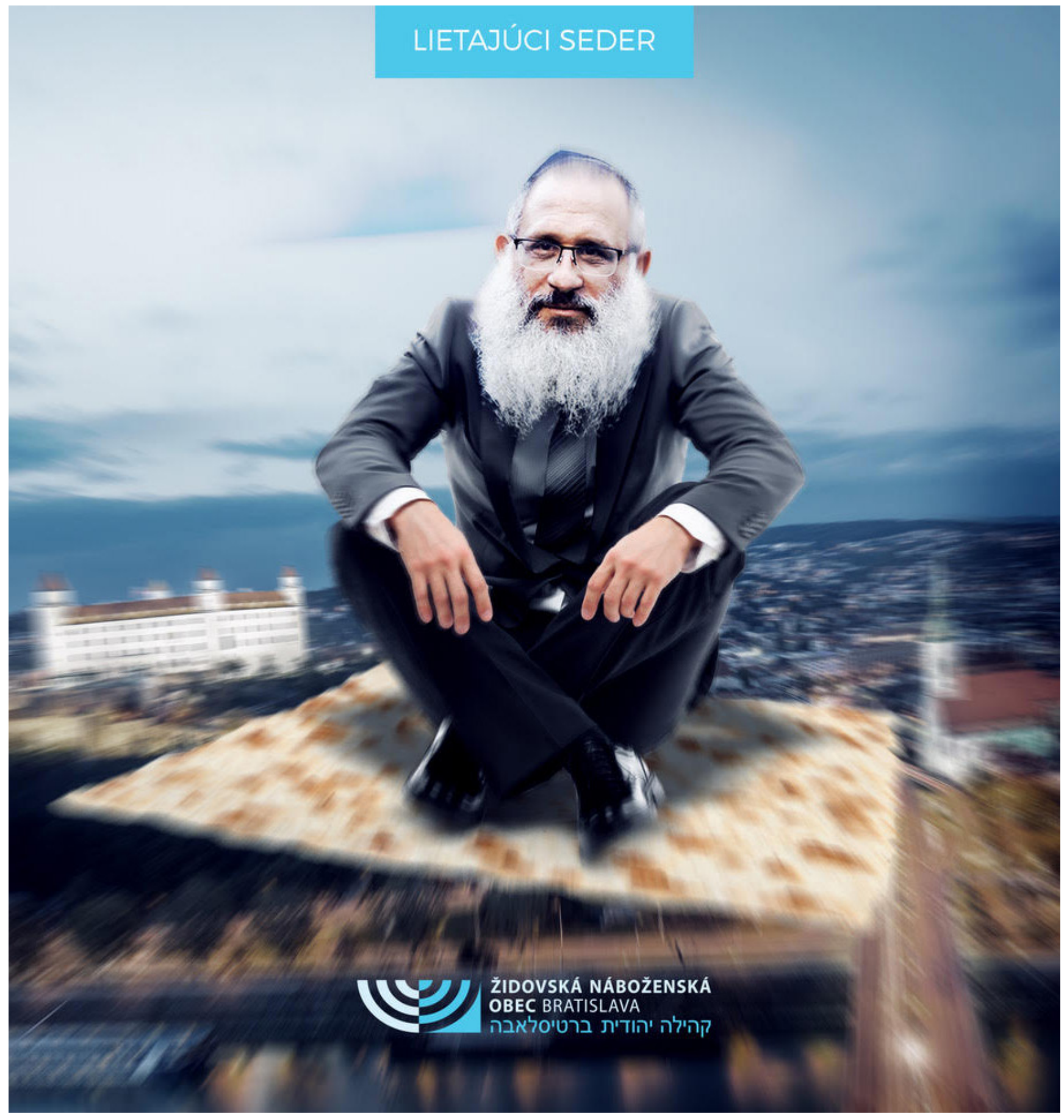

Obr. 2.

Lietajúci seder, Mail ŽNO Bratislava, 11. 4. 2020.

Zdroj: Peter Salner, 2020.

prinesie jednotlivcom i komunite ako celku viac než rok trvajúca (úplná alebo čiastočná) izolácia.

K reakciám na protipandemické opatrenia patrilo porovnávanie so situáciou židov počas holokaustu. Tieto paralely potvrdzujú, že židovská tragédia dodnes rezonuje vo verejnom priestore, ale aj fakt, že niektoré konkrétne prejavy sú dôkazom nepochopenia či dokonca vedomého zneužívania situácie v rokoch 1938 - 1945. Členovia židovskej komunity vnímajú takéto názory ako urážku. 


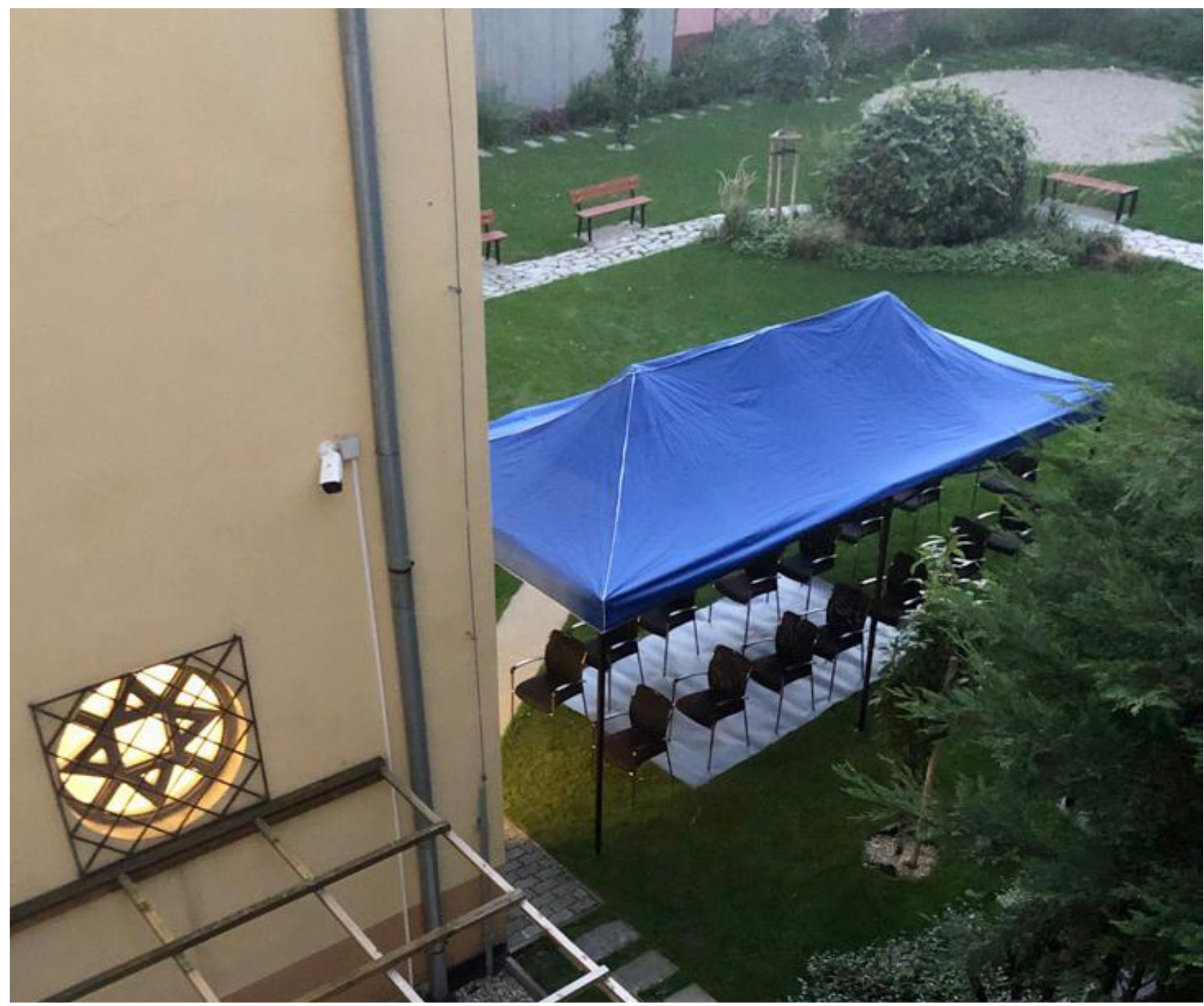

Obr. 3.

Roš HaŠaná: Provizórne sedadlá v záhrade synagógy. Zdroj: Soňa Salnerová, 2020.

Pandémia zároveň ukázala, že v období vážneho ohrozenia spoločnosti možno relatívne lahko prijat’ zákony, ktoré vedú k premene demokratickej spoločnosti na autoritársky či dokonca na totalitný režim. Vd’aka historickej skúsenosti najmä tí, ktorí zažili holokaust, vnímajú takéto potenciálne hrozby vel'mi citlivo:

Ja som raz čítala, že nižšie živočíchy rozoznajú nebezpečenstvo, áno, že napríklad vtáci zemetrasenie, a viete, že my máme v nás, tí čo sme prežili, taký sézmograf, my cítime, kde, kedy ide nebezpečenstvo a vám poviem, že sme znepokojení, lebo my sme prežili nielen jednu totalitu sprava, prežili sme aj druhú totalitu zl'ava...

(OH, Žena 1920/023).

Získané poznatky signalizujú, že antivaxeri na Slovensku sú v menšine, agresívnymi a hlučnými aktivitami však vytvárajú zdanie sily a početnosti. Vedome bojujú proti prijatým opatreniam, ktoré interpretujú ako obmedzovanie osobnej slobody či formu „moderného zotročenia“. Príslušníci židovskej komunity takéto názory a prejavy odmietajú. 
Pre budúcnost' bratislavskej (aj slovenskej) židovskej komunity je podstatné, či dokáže motivovat' členov (a to nielen najzranitel'nejšiu najstaršiu generáciu) k návratu do fyzických a duchovných priestorov obce. Odpoved' nie je jasná, pretože rok v izolácii nevyhnutne zmenil pravidelné sociálne kontakty, návyky a možno aj hodnoty. Generáciu preživších holokaust určite negatívne ovplyvní vek, zhoršený zdravotný stav i znížená schopnost' reakcie na nevyhnutné zmeny. Mladšie generácie zas majú k dispozícii široké spektrum iných možností, ako uspokojit svoje záujmy. Zvolené riešenia sa nemusia spájat's predstavami a potrebami ŽNO.

\section{Referencie}

Bumová, I. (2006a). Postoj ŠtB k emigrácii československých občanov v rokoch 1963 1983 (s dôrazom na Západoslovenský kraj). In D. Luther (Ed.), E/Migrácie a Slovensko (s. 41-74). Bratislava: Ústav etnológie SAV.

Bumová, I. (2006b). ŠtB a židovská mládež (na príklade Západoslovenského kraja v rokoch 1969 - 1989). In P. Salner (Ed.), Židovská komunita po roku 1945 (s. 67-100). Bratislava: Ústav etnológie SAV.

Denník N. (17. 11. 2020). Minúta po minúte: Proti vláde protestovali tisíce l'udí, prišli pred parlament aj úrad vlády. https://dennikn.sk/2146445/protest-koronavirus-kotlebacarnogursky/

Eichler, B. (b. d.). Príspevok k histórii Židov na Slovensku z doby druhej svetovej vojny až po október 1972. Toronto.

Eliáš, M. (2020). Epidémia koronavírusu pri súčasnom tempe vyvrcholí o 110 dní, nakazených bude 10\% l'udí. Webnoviny. https://www.webnoviny.sk/vzdravotnictve/ epidemia-koronavirusu-pri-sucasnom-tempe-vyvrcholi-o-110-dni-nakazenych-bude-10ludi/

Epstein, H. (1988). Children of the Holocaust: Conversations with Sons and Daughters of Survivors. London: Penguin Book.

Epsteinová, H. (1994). Děti holocaustu. Praha: Volvox Globator.

Harabin, Š. (23. 3. 2021). Rúško som nenosil, nenosím a pokial' mi Boh dá zdravie ani nosit nikdy nebudem, lebo nemám takú právnu povinnost'. Nulitné [Aktualizácia statusu]. Facebook. https://www.facebook.com/permalink.php?story_fbid=3037819206 494904\&id=1680731138870391

Havran, M. (23. 6. 2021). Na niektoré veci sa verejnosti nepýtame. Sme. https:// komentare.sme.sk/c/22688068/na-iste-veci-sa-verejnosti-nepytame.html

Hlavinka, J. (2005). Židovská komunita pod kontrolou. Štátna bezpečnost' a židovské náboženské obce na východnom Slovensku v prvej dekáde „normalizácie“. Pamät” národa, 2, 20-32.

Hospodárske noviny. (5. 6. 2020). „Hnusobu sme zastavili.“ Mistrík oznámil, že permanentný krízový štáb končí. https://slovensko.hnonline.sk/2163107-hnusobu-smezastavili-mistrik-oznamil-ze-permanentny krizovy-stab-konci 
Jablonková, Ch. (1998). Izrael a Židia zo Slovenska. Acta Judaica Slovaca, 4(1), 163-186. Jánošová, S. (26. 3. 2020). Myslím na tých, ktorým nikto nepovedal, aby ostali doma. Sme doma. https://zena.sme.sk/c/22368328/zostante-doma-v-marci-ineho-roka-by-steza-tuto-moznost-dali-hocico-html

Kamenec, I. (1988). Protižidovský pogrom v Topol'čanoch v septembri 1945. In J. Pecka (Ed.), Acta Contemporanea: K pětašedesátinám Viléma Prečana (s. 80-94). Praha: Ústav pro soudobé dejiny AV ČR.

Kern, M. (25. 6. 2021). Pellegriniho postoj k očkovaniu: nechce žltú hviezdu na saku a priznáva emócie na úkor faktov. Denník N. https://dennikn.sk/2445497/pellegrinihopostoj-k-ockovaniu-nechce-zltu-hviezdu-na-saku-a-priznava-emocie-na-ukorfaktov/?ref=tit

Madra, P. (19. 6. 2021). Nadýchnite sa slobody, núdzový stav sa skončil. Pandémia ešte nie. Pravda. https://spravy.pravda.sk/domace/clanok/587944-slobodne-sa-nadychnitenudzovy-stav-sa-skoncil-pandemia-este-nie/

Ministerstvo investícií, regionálneho rozvoja a informatizácie Slovenskej republiky (25. 6. 2021). Koronavírus a Slovensko. www.korona.gov.sk

Kozinets, R. (2015). Netnography: Doing Ethnographic Research Online. 2. vydanie. Los Angeles: SAGE Publications Ltd.

Lárišová, P. (2000). Židovská komunita v Bratis/ave v roku 1940. Historická demografia na základe sčítania l'udu. Bratislava: Nadácia Milana Šimečku, Ústav etnológie SAV, Židovská náboženská obec Bratislava.

Denník N. (17. 11. 2020). Minúta po minúte: Proti vláde protestovali tisíce l'udí, prišli pred parlament aj úrad vlády. https://dennikn.sk/2146445/protest-koronavirus-kotlebacarnogursky/

Newman, J. a Sivan, G. (1992). Judaismus od A do Z. Slovník pojmů a termínů. Praha: Sefer.

Ministerstvo vnútra Slovenskej republiky (30. 9. 2020). Od 1. októbra platína Slovensku núdzový stav. https://www.minv.sk/?tlacove-spravy\&sprava=od-1-oktobraplati-na-slovensku-nudzovy-stav

Rybárová, E. a Mosnáková, E. (3. 6. 2021). Seniori citia zadostučinenie, že sa o nich mladí pekne starajú. Sme Plus. https://plus.sme.sk/c/22664351/eva-mosnakova-senioricitia-zadostucinenie-ze-sa-o-nich-mladi-pekne-staraju.html.

Salner, P. (2006). Židovská emigrácia zo Slovenska po auguste 1968. In P. Salner (Ed.), Židovská komunita po roku 1945 (s. 301-322). Bratislava: Ústav etnológie SAV.

Salner, P. (2020a). Sviatok Pesach v dobe koronavírusovej pandémie (etnologická reflexia). Národopisná revue, 30(2), 162-165.

Salner, P. (2020b). Jewish Holidays in the Time of the Corona Virus Pandemic in Slovakia. Occasional Papers on Religion in Eastern Europe, 4O(6, 9), 110-121. 
Stern, T. (27. 1. 2021). Dnešné očkovanie preživších holokaust na ŽNO Bratis/ava úspešne dokončené. Židovská náboženská obec Bratislava. https://znoba.sk/sk/ aktivity-aktuality/1/dnesne-ockovanie-prezivsich-holokaust-na-zno-bratislava-uspesnedokoncene

Osvaldová, L. (26. 11. 2021). Rostas je obvinený z hanobenia rasy a národa, rozsudok potvrdil Najvyšší súd. Ak nezaplatí štyritisíc eur, pôjde za mreže. Denník N. https:// dennikn.sk/2586962/rostas-je-vinny-z-hanobenia-rasy-a-naroda-rozsudok-potvrdilnajvyssi-sud-do-sudnej-siene-ho-bez-ruska-nepustili/?ref=list

Uhlárik, Š. (23. 3. 2021). Harabin: Rúško som nenosil, nenosím a pokial' mi Boh dá zdravie ani nosit' nikdy nebudem! Hlavný Denník. https://www.hlavnydennik. sk/2021/03/23/harabin-rusko-som-nenosil-nenosim-a-pokial-mi-boh-da-zdravie-aninosit-nikdy-nebudem

Vrzgulová, M. (2007). Deti holokaustu. Bratislava: Dokumentačné stredisko holokaustu. Židovská náboženská obec Bratislava (26. 2. 2021). Druhé kolo očkovania preživších holokaust na ŽNO Bratis/ava. https://znoba.sk/sk/aktivity-aktuality/14/druhe-koloockovania-prezivsich-holokaust-na-zno-bratislava 